\title{
Teaching Business English with TED Talks: Putting Ideas into Practice
}

\author{
Olga Stognieva \\ National Research University Higher School of Economics
}

\begin{abstract}
Correspondence concerning this article should be addressed to Olga Stognieva, National Research University Higher School of Economics, Kirpichnaya, 33, Moscow, Russian Federation, 115187. E-mail: 2507794@mail.ru
\end{abstract}

\begin{abstract}
TED.com is used in teaching EFL to enhance exposure to English, to promote authentic vocabulary and to develop multiple foreign language skills. For university students studying business as their major and English for professional communication as a part of their university curriculum, TED talks provide a cutting-edge business context, which aims to increase the learners' English language proficiency, develop the learners' professional competencies and expand their outlook by acquainting them with business practices from around the world. Through authentic models of effective communication, students build fluency to achieve academic and personal success. Business English with TED talks, an EFL resource book, is the result of the author's approach to creating educational materials based on authentic and up to date video content. Using the example of 'Business English with TED talks', this paper describes criteria for selecting TED talks for different groups of students, the structure of a TED talk lesson and provides teachers with other resources for supplementing TED talk lessons.
\end{abstract}

Keywords: TED talks, business English, authentic video, teaching materials, integrated skills

\section{TED Talks as a Language Resource}

With the development of the internet, audiovisual input is accessible almost everywhere. Today, teachers and students have access to a vast variety of online audiovisual resources, which bring the outside world into the classroom, provide authentic contexts in which English is used, expose students to different varieties and accents of English, and give supplementary listening practice.

One well-known resource is TED.com, which has become a worldwide phenomenon. It is a platform where the brightest minds - scientists, designers, researchers, company CEOs and inventors - go to spread their ideas. Many of these leaders deliver their insights at TED conferences around the world, which are then uploaded onto TED.com. The scope of topics is broad and the materials are of very high quality, free of charge and constantly updated. There are about 380 talks on business, which can be used to the benefit of university students studying business as their major and also English for professional communication as a part of their university curriculum.

We live in a rapidly changing world but course books still take several years to be published. By then, the ideas, vocabulary, and educational context contained in the chosen texts is outdated and, as a result, has much less validity. The internet can fill this gap if the course books are supplemented by online material.

Being a supporter of the idea of teaching English with TED talks and having a strong desire to contribute to the implementation of this idea in teaching practice, the author created customized lessons using TED talks to provide authentic cutting-edge business contexts in which English is used.

The educational resource book entitled, Business English with TED talks ${ }^{1}$, is the result of the author's approach to creating educational materials based on authentic and up-to-date video recordings. It is a collection of ten lessons based on a selection of TED talks about business issues for university students whose level of proficiency in English is estimated as B2-C1, according to the Common European Framework of Reference for Languages (CEFR). The resource book can be used both for classroom activities and for independent student work and may

Stognieva, O. N. (2018). English for Business Studies in Higher Education (B2-C1). Moscow, Russia: Urait. 
be of interest to ESP instructors and university teachers of English as a foreign language. This article describes criteria for selecting TED talks for different groups of students, the structure of a TED talk lesson and provides teachers with other resources for supplementing TED talk lessons.

First, a brief review of existing literature is presented, followed by approaches to the lesson design that have been implemented. The article will conclude with a discussion of potential values and limitations that might be identified when using TED talks and suggestions for future research.

\section{The Benefits of TED Talks for EFL Teaching}

Video is a multi-sensory medium that offers students more than listening comprehension; videos provide students with an opportunity to be engaged meaningfully in using the target language (Terantino, 2011). Hanley, Herron and Cole (1995) suggest that multiple clues (colors, shapes, movements, voice) help language learners understand a particular discourse as well as to improve their integrated language skills. Incorporating video as an educational resource in EFL teaching practice can enhance exposure to the English language, promote authentic vocabulary and develop the four integrated skills (Mekheimer, 2011).

Using TED talks enhances listening comprehension skills. Herron and Seay (1991) reported about the cognitive and affective benefits from using authentic video-based materials to improve listening comprehension at all levels of instruction with no negative effect on grammar, vocabulary or oral skills. The research conducted by Chung (2002), employing authentic video in the EFL Taiwanese college classroom under the condition of combined treatment of pre-teaching vocabulary and question previewing, confirmed that authentic video materials produced a positive effect on listening comprehension instruction. Asako's study (2013) examined how TED talks affected Japanese college students' listening skills, and explored strategies to tailor the activities for lower-proficiency students. The data analysis indicated improvement in their listening comprehension, a rise of their level of motivation, and an increase in the ability to understand different English accents. Kim (2015) investigated the effect of implementing authentic video resources for improving listening comprehension among Korean university students. The results demonstrated a significant improvement in listening comprehension among the intermediate and advanced proficiency groups after using the videos.

TED talks are also a valuable material in increasing the students' reading comprehension skills. The recent studies of Hayikaleng, Nair and Krishnasamy (2016), Torabian and Tajadini (2017), Metruk (2018) investigated the effects of using authentic videos on EFL reading comprehension among vocational and university students, which indicated a significant achievement in reading comprehension of the experimental group compared to the control group. Results suggested that authentic videos might be considered as an effective instructional tool for improving English reading comprehension and as an important teaching resource in English classrooms.

Using authentic video helps develop writing skills (Hanley, et al., 1995). They compared the effects of two visual advance organizers on the comprehension and retention of a written passage in a FLES (Foreign Language in the Elementary School) program: (a) video and (b) pictures + teacher narrative. Their findings indicated that video was a more effective advance organizer than the pictures + teacher narrative. They interpreted these results as evidence of video's potential to enhance comprehension and enrich instruction. Other studies highlighted the benefits of using different types of authentic video (expository, observational, interactive and reflective) for essay composition (Snow, 2012); for narrative text writing in terms of content, organization, vocabulary, grammar (Anggraini et al., 2014); for introducing cohesion and coherence writing practices to university students (Indrasari, 2010).

TED talks provide language learners with the opportunity to improve their speaking skills. Weyers (1999) studied the effect of using authentic videos for Spanish learners' speaking output. The performance on both listening comprehension and oral production of the experimental group that was exposed to watching a television show for 60 minutes per day for 8 weeks was significantly better than the control group that followed the regular curriculum without the video. Kurniawan (2016) stated that the implementation of using movies as a medium to teach speaking was effective to boost the Indonesian EFL learners' average score in speaking. Abdelkarim (2016) emphasized that the authentic videos give enough exposure of language use, prepare students for speaking practices and help them to increase their level of achievement in speaking. In summary, the studies have shown that using video to improve students' speaking ability is appropriate. 
TED talks, accompanied by subtitles or transcripts, can help vocabulary learning. Canning-Wilson (2000) claims that images contextualized in video or on its own can help to reinforce the language, provided the learner could see immediate meaning in terms of vocabulary recognition in the first language. Although subtitles have sometimes been considered as distractors, nowadays the teacher should realize that "far from being a distraction and a source of laziness, subtitles might have a potential value in helping the learning acquisition process by providing learners with the key to massive quantities of authentic and comprehensible language input" (Vanderplank, 1988, p. 272-273). According to Talaván (2007), text in the form of bimodal subtitles (foreign language audio with foreign language subtitles) helps learners monitor a speech that would probably be lost otherwise. To use the subtitles efficiently, the instructor should teach students to use them as a support for learning new words, for better understanding, to fix spelling or any other functional purposes. The literature review indicates that using authentic video materials brings significant improvements to the whole language learning.

\section{Teaching and Learning Materials for Business English}

Business English is a broad term, which includes Englishes used by professionals and students in full-time education preparing for a business career. The teaching of business English, according to Brieger (1997), brings together three areas: the pedagogic skills involved in running training programs, knowledge of English and understanding the role of communication in a global business environment, and familiarity with the key business issues facing specific learners. Business English can be divided into English for Specific Business Purposes (ESBP) for language learners who are already working in business, and English for General Business Purposes (EGBP) for pre-experience language learners from universities, colleges or trade and commerce schools who have no experience of the business world (Ellis \& Johnson, 1994). This article reviews the teaching context of the second group - non-native pre-experience language learners. Dudley-Evans and John (2001) recommend published course book materials with input in text, audio and video format, which contains work on the traditional four skills as well as specific grammar and vocabulary development.

Many course books come as part of a package that includes comprehensive teacher's guides and resources, supplementary materials for students, self-study materials, audio and video resources. For pre-experienced groups, they may provide a window on to the business world. However, various limitations need to be considered when using published course books. Course books can quickly become outdated. Furthermore, the learners might have very specific requirements, depending on their cultural background and learning context. Important factors for them could include layout, structure, relevance, regular progress checks, up-to-date content, and authenticity. Price might also be a factor, depending on who is paying for the course (Frendo, 2005). That is why language practitioners should be aware of other types of teaching and learning materials for business English, such as job-specific materials, self-access materials, reference books, video materials, business simulation games, etc. (Sampath \& Zalipour, 2009).

Frendo (2005) claims that there are three types of business English materials for teaching and learning: framework materials, authentic materials and tailor-made materials. Framework materials are "diagrammatic representations which can be used to generate language", for example, the frameworks to describe 4Ps and SWOT analysis. "Authentic material is any kind of material taken from the real world and not specifically created for the purpose of language teaching" (Ellis, 1994). There are various sources of authentic materials, such as newspapers, magazines, company specific materials, YouTube videos. Tailor-made materials refer to materials that are designed or produced by the teacher to meet the specific needs of their students.

For pre-experienced students combining tailor-made materials with authentic materials is an effective method in teaching, which also aims at producing an authentic business context in the classroom (Sampath \& Zalipour, 2009). Business English instructors can select any authentic materials, for example TED talks, and adapt and tailor them to their students' needs and language proficiency level in order to produce relevant teaching aids.

TED.com provides 380 talks on business and their number is constantly increasing. However, few studies attempt to describe this educational resource as a tool for teaching business English. In recent studies, TED talks are mostly described in connection with extensive listening for enhancing listening skills (Elk, 2014; Park \& Cha, 2013; Takaesu, 2017; Wingrove, 2017); a means for improving the confidence and quality in delivering public speaking and the intonation of university students (Chang, \& Huang, 2015; Kusuma, 2017; McGregor, Zielinski, 
Meyers, \& Reed, 2016); a useful resource to promote vocabulary instruction (Nurmukhamedov, 2017; Uemura, 2016). This article contributes to filling a gap in the literature relating to how TED talks might be exploited for teaching business English to pre-experienced language learners.

\section{Potential learning values of TED talks in the EFL classroom}

Berk (2009, p. 2) distinguished 20 potential learning outcomes of authentic videos, such as movies, TV programs, commercials, and music videos in the classroom, which contribute to "energizing or relaxing students for learning exercise, drawing on students' imagination, improving attitudes toward content and learning, building a connection with other students and the instructor, increasing memorization of content". However, Berk's list does not exhaust the learning values of using TED talks in the EFL classroom.

\section{Immersion in authentic English}

TED talks are not originally produced as language teaching material, which means they serve an authentic real-world communicative purpose. Ciccone $(1995$, p. 205) underlines that "authentic video makes linguistic input more comprehensible by embedding it in a context of extra linguistic cultural clues that assures the transmission of meaning even when complete grammatical and lexical decoding is not likely to be achieved". For language teaching purposes, TED talks are reconsidered in a way to be pedagogically sound. They are beneficial for a monolingual university environment, which does not contribute to the development of foreign language proficiency outside the classroom.

TED talks are also authentic as the speakers' native language is not always English, which is exactly what EFL students are likely to encounter in real-life situations. "Videos expose students to authentic materials and to voices, dialects, and registers other than the teacher's and provide cultural contexts for the studied foreign language" (Chung \& Huang, 1998, p. 553). This is also useful for English language learners because it may help them to realize that they do not have to be afraid of the way they speak English.

\section{The personalization of learning}

From the point of view of English teaching methodology, the use of Business English with TED talks facilitates the personalization of learning, which is defined as an instruction that is paced to learning needs, tailored to learning preferences, and to the specific interests of different learners (Bray \& McClaskey, 2015). Personalization gives learners a sense of ownership and relevance. Personalized learning is about teachers working with students to customize instruction to meet the student's individual needs and interests (Kucirkova \& FitzGerald, 2015). Students with a lower level of English proficiency can progress through the material at their own speed. They have an opportunity to repeatedly return to the studied material until it becomes clear, use subtitles and transcripts of TED talks, slow down the recording, choosing their own pace of work.

\section{Providing a model for learner output}

Authentic video provides a good model for specific language items or a general pool for students to pick and choose from (Sherman, 2003). Having seen the model on video, learners can then produce their own version of the original. Learners usually have access to video cameras on their phones; the result can be an actual video. TED talk speakers may serve as role models for university students in terms of the development their presentation skills, as they use various public speaking techniques, visual and verbal supports to capture the attention of the audience.

\section{Inspiring and motivating students}

Bray \& McClaskey (2015) consider that learners want to be engaged with content and they want to learn more about something they are interested in. Stognieva (2018) claims that the content of the instruction tailored to learning needs and specific interests increases the motivation for learning a foreign language, which results in the rise of English language proficiency. TED talks that correspond to the students' interests stimulate their language use and improve other aspects of communication, providing interesting and motivating ideas. 


\section{Developing learner independence}

Different students have different learning strategies. A learning strategy is a person's approach to learning and using information. Students use learning strategies to help them understand information and solve problems. Learning strategy instruction focuses on making students more active learners by teaching them how to learn and how to use what they have learned to be successful (Passov \& Kuzovleva, 2010) ${ }^{2}$. While learning English with TED talks, students acquire specific learning strategies depending on the educational goals (with the emphasis on pronunciation, lexical, grammatical, writing or speaking skills, etc.). Learning with TED talks creates opportunities for more decentralized interaction. The teacher's role in this process is more as "a guide on the side than sage on the stage" (Warschauer \& Whittaker, 2002, p. 371).

\section{Broaden students' horizons}

Using TED talks aims not only at enhancing learners' English language proficiency but also at developing their professional competencies and expanding their outlook by acquainting them with ideas from around the world. "Video brings the outside world into the classroom" according to the National Geographic Learning mission. For example, Knut Haanaes, in his talk, 'Two reasons companies fail and how to avoid them' (2015), shares his insights on how to strike a balance between exploration and exploitation and explains how to avoid two major strategy traps. The real life context creates a meaningful learning environment and provides language learners with the opportunity to perceive new ideas in a foreign language.

\section{Criteria for Selecting TED Talks}

Selecting quality materials includes determining the degree to which they are consistent with the goals, principles, and criteria of the course curriculum. It is important to consider the teaching-learning context within which specific materials will be used (Berk, 2009). Well-defined selection criteria help more accurately choose and effectively utilize TED talks for achieving educational aims. Figure 1 illustrates the criteria for TED talks included in the resource book, Business English with TED talks.

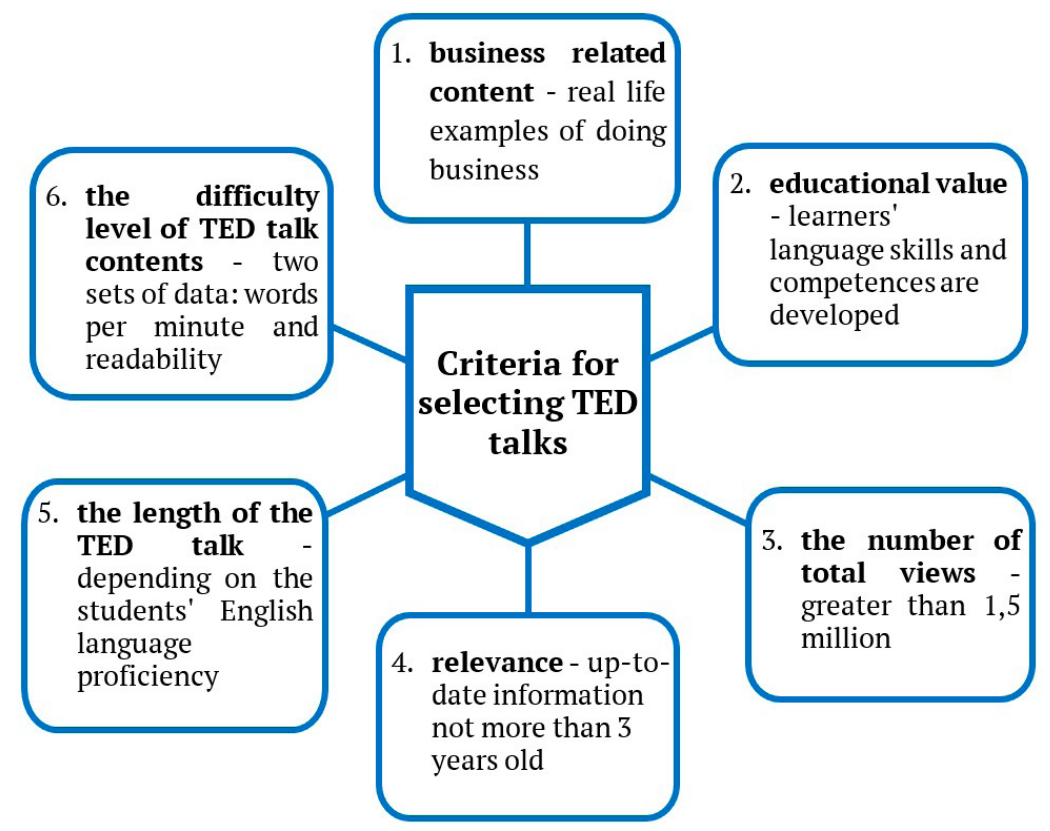

Figure 1. The selection criteria for 'Business English with TED talks'.

The talks, which were selected for the course 'Business English with TED talks', should meet the following criteria:

\footnotetext{
2 Passov, E.I., \& Kuzovleva, N.E. (2010). A lesson of a foreign language: Handbook for a teacher of foreign language. Moscow, Russia: Glossa-Press.
} 
1. The content of the TED talks should be relevant to the reason for showing the video, that is, to be solidly embedded in a meaningful context, satisfy the professional interests of the students and provide real life examples of doing business in an international environment.

2. The content of the TED talks should have an educational value. The problems discussed should develop the learners' linguistic and professional competencies and expand their outlook by acquainting them with business practices from around the world. The sequence of TED talks should fit in with the overall goals of the course, introduce or expand on a theme that is already part of the curriculum (Ciccone, 1995).

3. The popularity of the TED talk is measured in the number of views. The view count gives a reflection of how the audience responded to the information provided. In Business English with TED talks we selected talks with more than 1,5 million views.

4. The TED talks selected should provide relevant, up-to-date information and topics, which are interesting and motivating for the learners. Content older than 3 years was excluded.

5. The length of the TED talks should be determined by the students' language proficiency. Teachers might explore talks of different durations as set by TED.com (0-6 minutes, 6-12 minutes, 12-18 minutes, and $18+$ minutes). With low-level students, for example, a lengthy video material with many tasks could be discouraging. If EFL students are not yet familiar with lengthy transcripts then the shorter ones might work better for them.

6. The difficulty level of TED talk content can be determined by using Ted Corpus Search Engine (TCSE) (Yoichiro, 2015). TCSE is a free online search engine specializing in exploring transcripts of TED talks. It has been created for educational and scientific purposes. The database is big enough even though the number of talks might be less than displayed on TED.com. Figure 2 shows data from this corpus for two videos from the list in Table 1 below.

Sample 1.

Knut Haanaes:

Two reasons companies fail -- and how to avoid them

Кнуд Ханаэс: Две причины разорения компаний - и как этого избежать

Watch this talk on TCSE

Official TED page for this talk

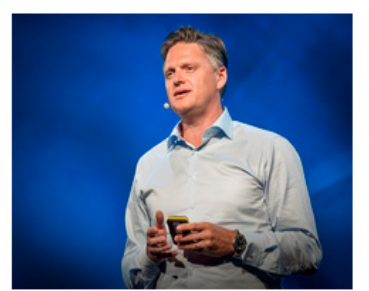

Recorded at June 30,2015

Event TED@BCGLondon

Num of elements 1610

Num of segments 200

Num of sentences 114

Duration (min:sec) 10:25

Words per minute 131.86

Readability (FK) $\quad 60.47$
Sample 2.

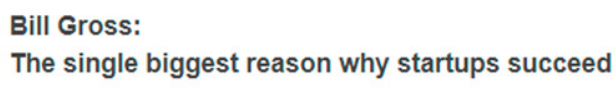

Билл Гросс: Одна из главных причин успеха стартапов

Watch this talk on TCSE

Official TED page for this talk

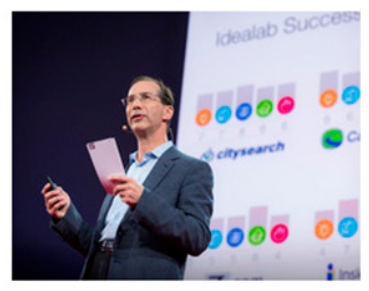

Recorded at March 19, 2015 Event TED2015

Num of elements 1536 Num of segments 164

Num of sentences 81

Duration (min:sec) 06:27 Words per minute 208.92 Readability (FK) 52.73 dificult

\section{Figure 2. The data from the TCSE.}

Two sets of data from TCSE are helpful for the video selection: words per minute, which determines the rate of speech, and readability, which indicates how difficult a passage is to understand (the higher the number the easy the text). Teachers may use this corpus to find data that support their selection from TED.com. They will be able to choose the level of content that is consistent with the students' language skills. For B1 students, Sample 1 (with the very slow speech tempo - 131 words per minute and readability of 60.47) might be a good option to start with, whereas Sample 2 (with very fast speech tempo - 209 words per minute and readability of 52.73) is a more challenging video that might fit the course for more advanced students.

Taking into consideration the above criteria, the following TED talks were selected for the course: 
Table 1

Compliance of TED talks with the selected criteria

\begin{tabular}{|c|c|c|c|c|c|c|c|}
\hline & Title & $\begin{array}{c}\text { Business related } \\
\text { content }\end{array}$ & $\begin{array}{l}\text { The number } \\
\text { of views }\end{array}$ & Date & $\begin{array}{c}\text { Length } \\
\text { (min) }\end{array}$ & $\begin{array}{l}\text { Words per } \\
\text { minute }\end{array}$ & $\begin{array}{l}\text { Read- } \\
\text { ability }\end{array}$ \\
\hline 1. & $\begin{array}{l}\text { 'How China is changing } \\
\text { the future of shopping' } \\
\text { (by Angela Wang) }\end{array}$ & $\begin{array}{l}\text { Advantages of } \\
\text { shopping via mobile } \\
\text { platforms }\end{array}$ & $1,588,583$ & 2017 & $13: 38$ & Slow & Difficult \\
\hline 2. & $\begin{array}{l}\text { 'How I became an } \\
\text { entrepreneur at } 66 \text { ' (by } \\
\text { Paul Tasner) }\end{array}$ & $\begin{array}{l}\text { It is never too late to } \\
\text { start a business }\end{array}$ & $1,900,037$ & 2017 & $6: 44$ & Very slow & Difficult \\
\hline 3. & $\begin{array}{l}\text { 'How to build a business } \\
\text { that lasts } 100 \text { years' (by } \\
\text { Martin Reeves) }\end{array}$ & $\begin{array}{l}\text { Principles from } \\
\text { living organisms for } \\
\text { businesses resilience }\end{array}$ & $1,953,066$ & 2016 & $14: 41$ & Very slow & Very difficult \\
\hline 4. & $\begin{array}{l}\text { 'The future of money' } \\
\text { (by Neha Narula) }\end{array}$ & $\begin{array}{l}\text { Digital currencies } \\
\text { transforming the world }\end{array}$ & $2,174,843$ & 2016 & $16: 03$ & Slow & Medium \\
\hline 5. & $\begin{array}{l}\text { 'The single biggest } \\
\text { reason why startups } \\
\text { succeed' (by Bill Gross) }\end{array}$ & $\begin{array}{l}\text { Five key factors for } \\
\text { startup success }\end{array}$ & $5,961,403$ & 2016 & $6: 27$ & $\begin{array}{l}\text { Very } \\
\text { fast }\end{array}$ & Difficult \\
\hline 6. & $\begin{array}{l}\text { 'Two reasons companies } \\
\text { fail - and how to avoid } \\
\text { them' (by Knut Haanaes) }\end{array}$ & $\begin{array}{l}\text { Balancing between } \\
\text { exploration and } \\
\text { exploitation }\end{array}$ & $1,946,192$ & 2015 & $10: 25$ & Very slow & Easy \\
\hline 7. & $\begin{array}{l}\text { 'Uber's plan to get more } \\
\text { people into fewer cars' } \\
\text { (by Travis Kalanick) }\end{array}$ & $\begin{array}{l}\text { Behind Uber's } \\
\text { business idea }\end{array}$ & $1,728,823$ & 2016 & $19: 05$ & Fast & Very Easy \\
\hline 8. & $\begin{array}{l}\text { 'What really motivates } \\
\text { people to be honest in } \\
\text { business' (by Alexander } \\
\text { Wagner) }\end{array}$ & $\begin{array}{l}\text { Inside the economics, } \\
\text { ethics and psychology } \\
\text { of business }\end{array}$ & $1,475,406$ & 2016 & $13: 14$ & Medium & Medium \\
\hline 9. & $\begin{array}{l}\text { 'Why jobs of the future } \\
\text { won't feel like work' (by } \\
\text { David Lee) }\end{array}$ & $\begin{array}{l}\text { Keeping relevant in } \\
\text { the age of robotics }\end{array}$ & $1,782,252$ & 2017 & $9: 52$ & $\begin{array}{l}\text { Very } \\
\text { fast }\end{array}$ & Difficult \\
\hline 10. & $\begin{array}{l}\text { 'Why the best hire might } \\
\text { not have the perfect } \\
\text { resume' (by Regina } \\
\text { Hartley) }\end{array}$ & $\begin{array}{l}\text { Some tips for human } \\
\text { resources executives }\end{array}$ & $3,661,229$ & 2015 & $10: 15$ & Very slow & Very difficult \\
\hline
\end{tabular}

The content of all the ten TED talks satisfies the professional interests of our Business Informatics students, provides real life examples of doing business, has educational value and is up-to-date. The other two criteria vary in terms of the length of the recording, the difficulty level of TED talk contents and might satisfy different teaching and learning needs. 


\section{OLGA STOGNIEVA}

\section{The structure of a TED talk lesson}

Each lesson has a regular structure:

Warm-up introduces the topic and target language of the lesson, sets the atmosphere and the expectations of the lesson.

Vocabulary section introduces new words, their use and provides practice for the students.

Listening section aims at developing various types of listening skills applying the strategies of a successful listener.

Reading section aims at developing various types of reading skills applying the strategies of a successful reader.

Speaking section aims at discussion and response to the content of the TED talk.

Writing section responds to the content of the TED talk and reflects students' personal reactions in applying the conventions of academic writing in English.

A more detailed lesson structure is described in Table 2.

Table 2

TED talk lesson structure

\begin{tabular}{|c|c|c|}
\hline $\begin{array}{l}\text { Lesson } \\
\text { structure }\end{array}$ & Types of activities & Teaching aims \\
\hline Warm-up & 1. Discuss the following questions with your partner. & $\begin{array}{l}\text { - to set a suitable context; } \\
\text { - to activate students' relevant prior knowledge }\end{array}$ \\
\hline Vocabulary & $\begin{array}{l}\text { 1. Match the words with their definitions } \\
\text { 2. Practice the words online (www.quizlet.com) } \\
\text { 3. Fill in the gaps with the new words in the appropriate form } \\
\text { 4. Study the two lists of words; match the words in the box } \\
\text { with similar meaning. } \\
\text { 5. Complete the crossword or find the words from the lesson in } \\
\text { the word search box. (www.proprofs.com) }\end{array}$ & $\begin{array}{l}\text { - to familiarize students with the new vocabulary units; } \\
\text { - to help them to memorise the vocabulary units; } \\
\text { - to practice specific language points, items of grammar } \\
\text { and vocabulary; } \\
\text { - to engage students in the learning process and } \\
\text { reinforce the vocabulary units }\end{array}$ \\
\hline Listening & $\begin{array}{l}\text { 1. Watch the TED talk and make notes. Decide on the effective } \\
\text { method of notetaking (such as the Cornell method, the } \\
\text { outlining method, the mapping method, the charting } \\
\text { method). These are given to the students as prompts prior } \\
\text { to the lesson) } \\
\text { 2. Using your notes, answer comprehension questions }\end{array}$ & $\begin{array}{l}\text { - to practice note taking skills; } \\
\text { - to practice listening for gist (general comprehension); } \\
\text { - listening to learn (content-based input); } \\
\text { - to practice using notes }\end{array}$ \\
\hline Reading & $\begin{array}{l}\text { 1. Reconstruct the summary of the TED talk by selecting the } \\
\text { right sentence to fill each gap in the text from a list of } \\
\text { options } \\
\text { 2. Complete the summary of the TED talk with the words from } \\
\text { the box in an appropriate form; } \\
\text { 3. Read the summary of the TED talk and choose the most } \\
\text { suitable heading for each paragraph from the list of the } \\
\text { headings } \\
\text { 4. Read the script of the TED talk and make notes about } \\
\text { advantages and disadvantages (of some phenomenon); } \\
\text { 5. Fill in the table with the specific information indicated in } \\
\text { the script of the TED talk; } \\
\text { 6. Read the script of the TED talk and fill in the time line } \\
\text { (reconstructing the order of events) }\end{array}$ & $\begin{array}{l}\text { - to employ a variety of reading skills including } \\
\text { - prediction, reading for gist, scanning and intensive } \\
\text { reading; } \\
\text { - to make use of contextual clues to infer meanings of } \\
\text { unfamiliar words from context }\end{array}$ \\
\hline Speaking & $\begin{array}{l}\text { 1. Using your notes reconstruct the TED talk with your } \\
\text { partner. } \\
\text { 2. Reproduce the talk to another student. In pairs, or in small } \\
\text { groups, discuss questions reflecting the debatable issues in } \\
\text { the TED talk. } \\
\text { 3. For example, Are you for or against...? Why? Do you agree ... } \\
\text { ? How do you understand ... ? What if ...? }\end{array}$ & $\begin{array}{l}\text { - to stimulate discussion and response to the content } \\
\text { of the TED talk; } \\
\text { - to use appropriate communication strategies to } \\
\text { participate in group and class discussions }\end{array}$ \\
\hline
\end{tabular}




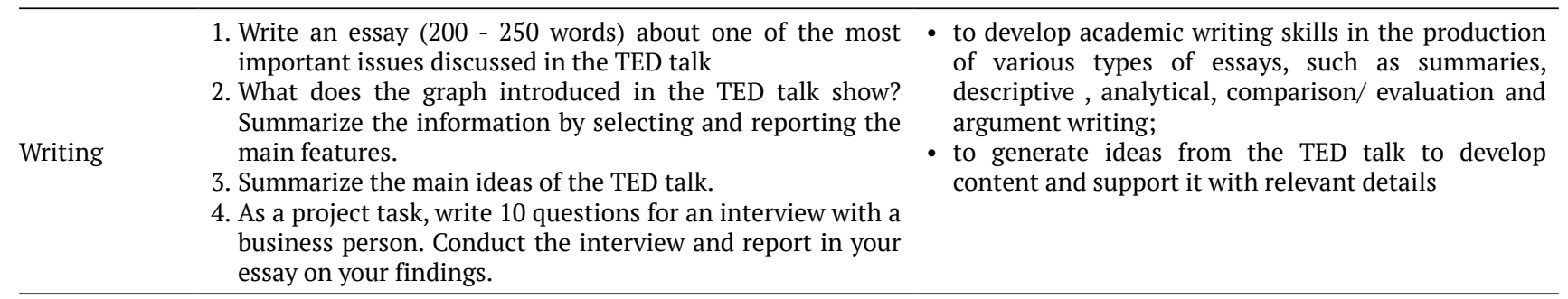

The distinctive feature of Business English with TED talks is that each lesson includes activities that are aimed at the development of all integrated skills: reading, listening, speaking, writing. The need for integrated learning is explained by the patterns of foreign language acquisition - the more senses involved in language learning, the more successful the results will be. If the students have the opportunity to watch and listen to the material, read it, discuss it and write about it, the assimilation of a foreign language is significantly increased (Passov \& Kuzovleva, 2010).

The TED talk is treated as a conversational text, which serves a meaningful content base for all the lesson activities. The students should not only comprehend and retell the main ideas of the TED talk, but by expressing their attitude to the content of the text, they should respond to various tasks using vocabulary units and language models learned from the current lesson, as well as the vocabulary units learned from previous lessons. Due to the combination mechanisms, vocabulary skills are developed.

The sample lesson presented in the Appendix is an example of how the approaches described above can fit a 90 minute lesson. A written assignment may be given to the student as homework. Obviously, any part of the lesson can be modified to suit each teacher's or each classroom's needs. The piloting of Business English with TED talks took place in the 2017-2018 academic year while teaching Business English course (ESAP module) at the Business and Management Department of the National Research University Higher School of Economics, Moscow, Russia.

\section{Other resources for supplementing TED talk lessons}

Special attention in Business English with TED talks is given to vocabulary acquisition and practice. Some vocabulary activities are created at the free websites www.quizlet.com and www.proprofs.com, which is advantageous for teachers and students. It allows teachers to expand the restricted classroom time and it allows students to strengthen their vocabulary skills with appropriate guidance. Quizlet is as an effective memorization tool to assist students' learning. It offers a variety of learning modes, such as creating flashcards, typing what you hear, generating random tests, matching terms and definitions, typing while memorizing. ProProfs Quiz Maker has a wide variety of templates to choose from; users can easily create quizzes to meet their individual needs. Quizlet and ProProfs Quiz Maker do not require the installation of software and both of them can be operated in mobile devices. They are fun and motivating for students.

\section{Conclusion}

This article illustrates some benefits that can be gained from using TED talks for university students, studying Business English. Bacon and Finneman (1990) commented that learning to deal with authentic input is the true measure of language proficiency. TED talks, as an authentic EFL resource, can enhance exposure to English language, promote authentic vocabulary and develop the four integrated skills: listening, writing, reading and speaking. For university students, it is important that, along with the language itself, they acquire skills that will be useful in their future career, such as extracting information, analyzing problems, producing summaries and reports, describing bar charts and graphs. TED talk content is beneficial for overall professional development. Through authentic models of effective communication, students build fluency to achieve academic and personal success.

TED talks can be used for creating customized lessons for university students studying not only business but also other subjects such as computer studies, marketing, design, medicine, psychology. There are more than 100,000 videos on a wide variety of subjects and the number grows daily. 
TED talks should be selected according to the proposed criteria (professionally relevant content, language value, the number of views, date) to fit with the overall goals of the course. First, the subject of the course should be identified and the scope of lessons determined. The outlined lesson design and the types of activities corresponding to the teaching aims, including other resources, should be developed. Finally, the lesson should be piloted in the classroom to ensure that it is well designed and adapted if needed.

There are some limitations. First, given the complexity of the whole task and the vastness of the Ted talk collection, time must be spent in order to prepare well-structured lessons. In using TED talks, a lot depends on the teacher's determination, creativity and lesson planning skills (to decide how to use, where and when to embed them). Secondly, technical resources are required, which may not be available in every teaching context. Nevertheless, TED.com is a valid resource for teachers seeking to enhance their lessons with authentic, topical content. Future studies could compile quantitative data to investigate the educational value of teaching with Business English with TED talks on the students' language output and estimate to what extent the consistent embedding of lessons based on TED talks result in developing listening, reading, writing and vocabulary skills of the university students.

\section{References}

Abdelkarim, R. (2013). The effectiveness of using authentic videos in developing students' speaking skill. Retrieved from http://dspace.univ biskra.dz:8080/jspui/bitstream/123456789/5312/1/SE284.pdf

Anggraini, Y., Yasin, A., \& Radjab, D. (2014). Improving students' writing skill of narrative text through video at Grade XII IPA 2 of SMAN 2 Bukittinggi. Journal English Language Teaching, 2(2), 79-92.

Asako, T. (2013). TED Talks as an extensive listening resource for EAP students. Language Education in Asia, 4(2), 150-162. Retrieved from http://dx.doi.org/10.5746/LEiA/13/V4/I2/A05/Takaesu

Bacon, S. M., \& Finneman, M. D. (1990). A study of the attitudes, motives, and strategies of university foreign language students and their disposition to authentic oral and written input. The Modern Language Journal, 74(4), 459-473. Retrieved from http://dx.doi.org/10.1111/j.1540-4781.1990.tb05338.x

Berk, R. A. (2009). Multimedia teaching with video clips: TV, movies, YouTube, and mtvU in the college classroom. International Journal of Technology in Teaching and Learning, 5(1), 1-21.

Brieger, N. (1997). Teaching Business English. York, UK: York Associates Publications.

Canning-Wilson, C. (2000). Practical aspects of using video in the foreign language classroom. The Internet TESL Journal, 4(11). Retrieved from http://iteslj.org/Articles/Canning-Video.html

Chang, Y. J., \& Huang, H. T. (2015). Exploring TED talks as a pedagogical resource for oral presentations: A corpus-based move analysis. English Teaching \& Learning, 39(4), 29-62.

Chung, J. M., \& Huang, S. C. (1998). The effects of three aural advance organizers for video viewing in a foreign language classroom. System, 26(4), 553-565.

Chung, J. M. (2002). The effects of using two advance organizers with video texts for the teaching of listening in English. Foreign Language Annals, 35(2), 231-241.

Ciccone, A. (1995). Teaching with authentic video: theory and practice. In F.R. Eckman, D.D. Highland, P.W. Lee, J. Milman \& R.R. Weber (Eds.), Second language acquisition: Theory and Pedagogy (pp. 203-218). Mahwa, NJ, Psychology Press.

Danan, M. (1992). Reversed subtitling and dual coding theory: New directions for foreign language instruction. Language Learning, 42, 497-527. doi: https://doi.org/10.1111/j.1467-1770.1992.tb01042.x

Dudley-Evans, T., \& John, M. J. (2001). Developments in English for specific purposes. Cambridge, UK: Cambridge University Press.

Eckman, F. R., Mileham, J., Weber, R. R., Highland, D., \& Lee, P. W. (2013). Second language acquisition theory and pedagogy. New York, NY: Routledge.

Elk, C. K. (2014). Beyond mere listening comprehension: Using TED Talks and metacognitive activities to encourage awareness of errors. International Journal of Innovation in English Language Teaching and Research, $3(2), 215-230$.

Ellis, M., \& Johnson, C. (1994). Teaching Business English. Oxford, UK: Oxford University Press.

Frendo, E. (2005). How to teach business English. London, UK: Pearson Education Limited.

Hanley, J., Herron, C., \& Cole, S. (1995). Using video as an advance organizer to a written passage in the FLES Classroom. The Modern Language Journal, 79(1), 57-66. 
Hayikaleng, N., Nair, S. M., \& Krishnasamy, H. N. (2016). Using YOUTUBE to improve EFL reading comprehension among vocational students. Proceedings of the ICECRS, 1(1), 391-398. Retrieved from http://ojs.umsida.ac.id/ index.php/icecrs/article/view/507/429

Herron, C. \& Seay, I. (1991). The effect of authentic aural texts on student listening comprehension in the foreign language classroom. Foreign Language Annals, 24, 487-95.

Herron, C. A., Morris, M., Secules, T., \& Curtis, L. (1995). A comparison study of the effects of video-based versus text-based instruction in the foreign language classroom. The French review, 68(5), 775-794.

Indrasari, N. (2010). Improving students' writing skill of narrative texts by using short videos (Unpublished Bachelor Thesis). Sebelas Maret University, Surakarta. Retrieved from file://C:/Users/ST/Downloads/3811. pdf

Kim, H. (2015). Using authentic videos to improve EFL students' listening comprehension international. Journal of Contents, 11(4), 15-24. http://dx.doi.org/10.5392/IJoC.2015.11.4.015

Kurniawan, F. (2016). The use of audio visual media in teaching speaking. English Education Journal, 7(2), 180193. Retrieved from http://www.jim.unsyiah.ac.id/READ/article/view/7167/3185

Kusuma, L. A. (2017). Islamic-Content-TED public speaking as a source material for improving Islamic student's communication skill. Journal of English Educators Society, 2(2), 75-90.

McGregor, A., Zielinski, B., Meyers, C., \& Reed, M. (2016). An exploration of teaching intonation using a TED Talk. In J. Levis, H. Le, I. Lucic, E. Simpson, \& S. Vo (Eds.), Proceedings of the 7th Pronunciation in Second Language Learning and Teaching Conference (pp. 143-49). Ames, IA: Iowa State University.

Mekheimer, M. (2011). The impact of using videos on whole language learning in EFL context. Arab World English Journal Volume, 2(2), 5-39.

Metruk, R. (2018). The effects of watching authentic English mideos with and without subtitles on listening and reading skills of EFL learners. EURASIA Journal of Mathematics, Science and Technology Education, 14(6), 2545-2553.

Nurmukhamedov, U. (2017). Lexical coverage of TED Talks: Implications for vocabulary instruction. TESOL Journal, 8(4), 768-790. https://doi.org/10.1002/tesj.323

Park, S. M., \& Cha, K. W. (2013). Pre-service teachers' perspectives on a blended listening course using TED Talks. Multimedia-Assisted Language Learning, 16(2), 93-116.

Sampath, D., \& Zalipour, A. (2009). Practical approaches to the teaching of business English. In Proceedings of the 2nd International Conference of Teaching and Learning (ICTL 2009) (pp. 1-14). Nilay, Malaysia: INTI University College. Retrieved from https://my.laureate.net/Faculty/docs/Faculty\%20Documents/INTI\%20 Conferences/Parallel\%20Sessions\%202/2C/2C-06-P150\%20(Malaysia).pdf

Sherman, J. (2003). Using authentic video in the language classroom. Cambridge, UK: Cambridge University Press.

Snow, Z. (2012). The cinematic essay: Argumenative writing and documentary film (Unpublished Master dissertation). Clemson University, South Carolina. Retrieved from https://tigerprints.clemson.edu/cgi/ viewcontent.cgi?article $=2322 \&$ context=all_theses

Takaesu, A. (2017). TED Talks as an Extensive Listening Resource for EAP Students. Language Education in Asia, 4(2), 150-162. http://dx.doi.org/10.5746/LEiA/13/V4/I2/A05/Takaesu

Talaván, N. (2006). Using subtitles in a multimedia environment to enhance listening comprehension for foreign language students of English. Porta Linguarum, 6, 41-52.

Terantino, J. M. (2011). YouTube for foreign languages: You Have to See this Video. Language Learning \& Technology, 15(1), 10-16.

Torabian, A., \& Tajadini, M. (2017). Fostering EFL learners' reading comprehension: Animation film technique. Advances in Language and Literary Studies, 8(2), 55-63. http://dx.doi.org/10.7575/aiac.alls.v.8n.2p.55

Uemura, T. (2016). Are TED talks a good role model for ESL and EFL users? In S.N. Dita \& W.D.W. Gonzales (Eds.),In Proceedings of the 10th International Conference of the Asian Association for Lexicography (pp. 207215). Manila, The Philippines: University of the Philippines.

Vanderplank, R. (1988). The value of teletext sub-titling in language learning. ELT Journal, 42, 272-281.

Warschauer, M., \& Whittaker, P. (2002). The Internet for English teaching: Guidelines for teachers. In J. Richards \& W. Renandya (Eds.), Methodology in language teaching: An anthology of current practice (Approaches and methods in language teaching, pp. 368-373). Cambridge: Cambridge University Press. doi: https://doi. org/10.1017/CBO9780511667190.053

Wetzel, C. D., Radtke, P. H., \& Stern, H. W. (1994). Instructional effectiveness of video media. Hillsdale, NJ: Lawrence Erlbaum.

Weyers, J. R. (1999). The effects of authentic video on communicative competence. The Modern Language Journal, 83(3), 339-349. 


\section{OLGA STOGNIEVA}

Wingrove, P. (2017). How suitable are TED talks for academic listening? Journal of English for Academic Purposes, 30, 79-95.

Yoichiro, H. (2015). Design and implementation of an online corpus of presentation transcripts of TED talks. Procedia: Social and Behavioral Sciences, 198(24), 174-182. 


\section{Appendix}

\section{The single biggest reason why startups succeed ${ }^{3}$}

What is the secret ingredient for startup success? Most people reckon that a great idea is the most important element. However, Idealab founder Bill Gross corrects this faulty assumption. His analysis of 200 companies, including some landmark successes as well as notable failures, reveals that timing is everything. Gross's findings could not come at a better time for today's ambitious entrepreneurs and venture capitalists.

In this lesson, you will learn:

$>$ Why many high-potential startups fail;

$>$ What five factors influence the chances of a startup's success;

Dhich of these elements is the most important in determining a startup's fate.

The video for this lesson is available at https://www.ted.com/talks/bill_gross_the_single_biggest_reason_why_ startups_succeed

\section{Warm-up}

Discuss the following questions with your partner:

- What is a startup?

- What do you need to create a startup?

- Would you like to found a startup in the future?

- Why do startups have high rates of failure?

\section{Vocabulary}

1. Match the words with their definitions:

\begin{tabular}{|c|c|}
\hline 1. to account & a newly established business \\
\hline 2. adaptability & $\begin{array}{l}\text { the quantitative relation between two amounts showing the number of times one value contains or is contained } \\
\text { within the other }\end{array}$ \\
\hline 3. attribute & the act of doing or performing something, especially in a planned way \\
\hline 4. broadband & a period when the economy of a country is not successful and conditions for business are bad \\
\hline 5. business model & $\begin{array}{l}\text { the income generated from sale of goods or services, or any other use of capital or assets, before any costs or } \\
\text { expenses are deducted }\end{array}$ \\
\hline 6. competitor & the extent to which a product, idea, etc., gains popularity or acceptance \\
\hline 7. customer & an organization engaged in commercial or economic competition with others \\
\hline 8. execution & $\begin{array}{l}\text { a high-capacity data transmission technique using a wide range of frequencies, which enables a large number of } \\
\text { messages to be communicated simultaneously }\end{array}$ \\
\hline 9. funding & the quality of being able to adjust to new conditions \\
\hline 10. penetration & $\begin{array}{l}\text { a design for the successful operation of a business, identifying revenue sources, customer base, products, and } \\
\text { details of financing }\end{array}$ \\
\hline
\end{tabular}

3 Gross, B. (2016). The single biggest reason why startups succeed. Retrieved from https://www.ted.com/talks/bill_gross_the_single_biggest_reason_ why_startups_succeed 


\section{OLGA STOGNIEVA}

11. ratio selecting the best time or speed for doing something in order to achieve the desired or maximum result

12. recession a person or organization that buys goods or services from a shop or business

13. revenue money provided, especially by an organization or government, for a particular purpose

14. startup the extent to which a product is recognized and bought by customers in a particular market

15. timing to think of someone or something in the stated way

16. traction a quality or characteristic that someone or something has

2. Practice the words online https://quizlet.com/_4h1bto

3. Study the two lists of words. Match the words in box with similar meaning:

\begin{tabular}{ll}
\hline \multicolumn{1}{c}{$\mathbf{1}$} & \multicolumn{1}{c}{$\mathbf{2}$} \\
\hline customer & characteristic \\
recession & company \\
account & financing \\
attribute & client \\
adaptability & propagation \\
competitor & decline \\
funding & rival \\
startup & performance \\
penetration & judge \\
execution & flexibility \\
\hline
\end{tabular}

4. Fill in the gaps with the words from Ex.1. in the appropriate form:

1) I believe that the organization is one of the greatest forms to make the world a better place.

2) That company came out right during the height of the when people really needed extra money.

3) Then I looked at the the most important thing?

4) It was too hard to watch video content online in 1999 because was too low.

5) I think business model is not so important because you can start out without it and add one later if your are demanding what you are creating.

6) Uber is an incredible company with incredible and great execution, too.

7) Timing for 42 percent of the difference between success and failure.

8) Team and ___ came in second, and the idea actually came in third.

9) We thought that GoTo.com succeeded because the idea was so great, but actually, the more important.

10) If you are underfunded at first but you are gaining , it is very easy to get intense funding.

5. Solve the crossword. You may complete the task online following the link https://www.proprofs.com/games/ crossword/the-single-biggest-reason-why-startups-succeed/ or in your course book: 
Across

2. A quality of being able to adjust to new conditions

4. An organization engaged in commercial or economic competition with others

5. A person or organization that buys goods or services from a shop or business

\section{Down}

1. The extent to which a product, idea, etc., gains popularity or acceptance

3. A quality or characteristic that someone or something has

6. Money provided, especially by an organization or government, for a particular purpose

7. The selecting of the best time or speed for doing something in order to achieve the desired or maximum result

8. The quantitative relation between two amounts showing the number of times one value contains

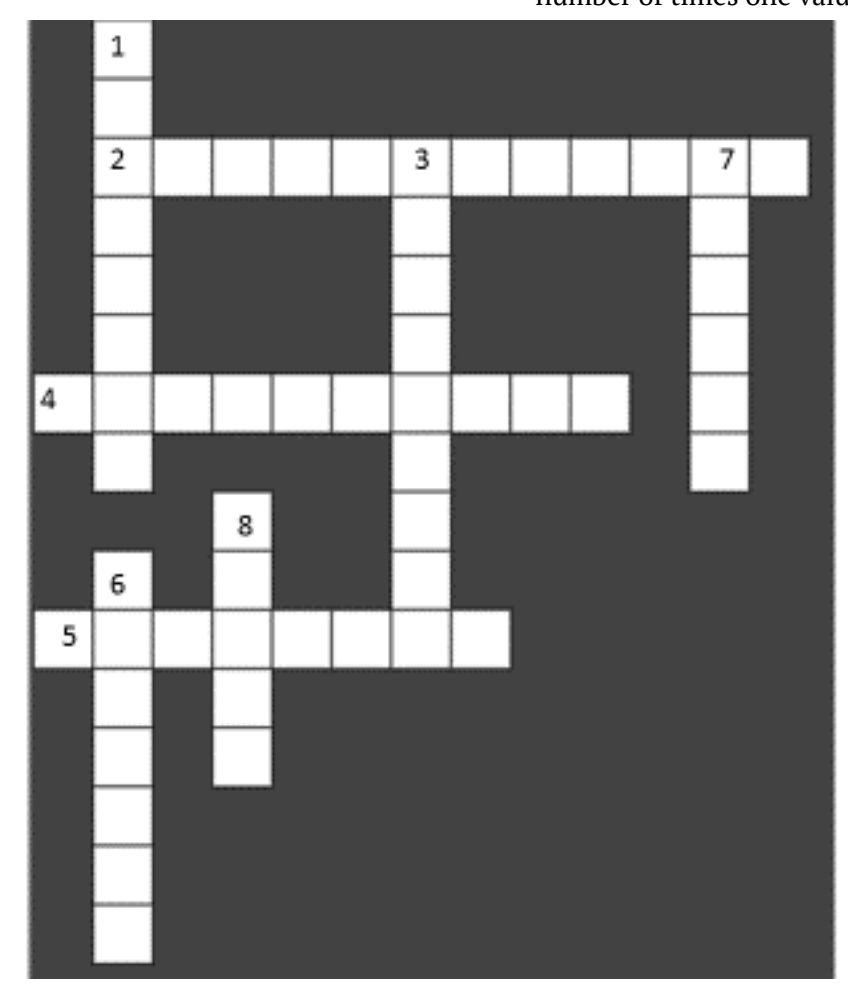

\section{Comprehension}

1. Watch the TED talk and make notes. Decide on how you are going to make notes.

2. Using your notes, answer the following questions:

1) What age did Bill Gross, the Idealab founder, start his first business? What was it?

2) What other businesses did he start?

3) What factors determine a company's success or failure?

4) What did Bill Gross mean by quoting the boxer Mike Tyson: "Everybody has a plan, until they get punched in the face"?

5) What was Bill Gross's research based on?

6) How many companies did he analyze in total?

7) What are the findings of his research?

8) What specific examples can illustrate his findings?

9) Why does Bill Gross believe the startup organization is one of the greatest methods to make the world a better place? 


\section{OLGA STOGNIEVA}

\section{Reading}

1. Read the summary of the TED talk and reconstruct the text by selecting the right sentence to fill each gap in the text.

A. Surprisingly, team and execution ranked second, and idea ranked third.

B. Or could funding - having enough money to see the idea through to fruition - be the deciding factor?

C. The startup organization is one of the greatest forums to make the world a better place.

D. At first, Gross believed that the essential characteristic of a winning firm was a great idea.

E. Broadband penetration was still too low, and watching videos online made for a poor user experience.

F. The timing for Airbnb could not have been better.

Why do some companies succeed while others fail? Idealab, a business incubator, has supported more than 100 startups over the past 20 years, including many overwhelming triumphs and disappointing duds, which places Bill Gross, CEO of Idealab, in an ideal position to investigate the secret of success. Gross analyzed 100 Idealab companies plus 100 external companies in an effort to determine which of five factors - idea, team, business model, funding and timing - exerts the greatest influence on the fate of a new business. (1) Over time, he began to think that the team and idea execution were more important than a great concept. After all, once a product or service goes to market and consumers begin to weigh in, execution is critical. But perhaps the business model the way a company monetizes its idea - determines the destiny of a firm. (2) Or how about timing? Many great ideas fail simply because they were ahead of their time or came too late.

The companies in Gross's sample included runaway successes such as Citysearch, NetZero, Tickets.com, Airbnb, Instagram and Uber. It also included spectacular failures: companies with strong funding and a clear business model, such as Pets.com, Friendster and Webvan. Gross's analyses found that the deciding factor in the success or failure of these businesses was timing. (3) A startup's funding and business model are not initially integral to the success of a business because enterprises can launch and grow without having these two elements in place.

Many investors passed on Airbnb because they couldn't imagine that people would open their homes to strangers. Yet the startup launched during the recession when people embraced new ways to bring in income. (4) The recession also helped Uber attain success, because so many people were willing to drive to earn extra money. In contrast, Z.com, an entertainment company that launched in 1999, was ahead of its time. (5) Just a few years after Z.com folded, the market was primed for YouTube, which attained huge success with a similar idea. When it comes to startup success, timing is everything, and the best way assess if the time is right for your idea is to ascertain objectively if the consumer is ready.

2. Fill in the table below with the specific information indicated in the transcript:

\begin{tabular}{|l|l|l|}
\hline \multicolumn{1}{|c|}{ Company } & Industry & Reasons it succeeded \\
\hline Airbnb & & \\
\hline Uber & & \\
\hline Citysearch & & \\
\hline GoTo.com & & \\
\hline YouTube & & \\
\hline
\end{tabular}




\section{Speaking}

1. Using your notes, reconstruct the TED talk with your partner.

2. Reproduce the talk to another pair of students.

3. In pairs, or in small groups, discuss the following questions:

1) Why do many startup organizations fail before they achieve their goal?

2) Gross's study demonstrates that while having a great idea is important, timing matters the most when launching a new enterprise. Why is this so?

3) Ron Conway, a notable American startup investor, claims: "Any time is a good time to start a company." Does he contradict Bill Gross's ideas and why?

4) Guy Kawasaki, a Silicon-Valley based author, speaker and entrepreneur says: "Ideas are easy. Implementation is hard.” Do you agree?

\section{Writing}

1. Write an essay (200 - 250 words). Use Figure 1 for additional information.

2. What is the most crucial factor in determining the success of a startup?

Top 5 Factors in Success Across More Than 200 Companies

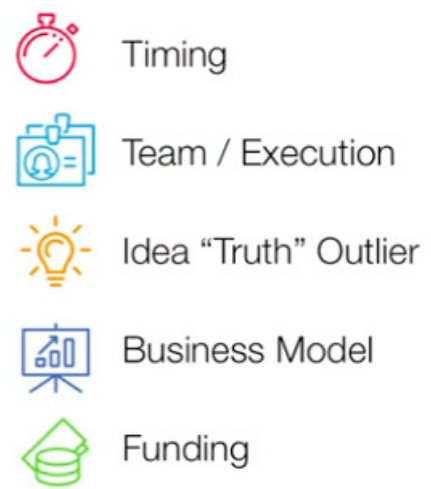

\section{$42 \%$}

$32 \%$

$28 \%$

$24 \%$

$14 \%$

Figure 1. 